\title{
Soil Phosphorus and Agricultural Development in the Leeward Kohala Field System, Island of Hawai ${ }^{i}{ }^{1}$
}

\author{
Molly Meyer, ${ }^{2,3}$ Thegn N. Ladefoged, ${ }^{4,6}$ and P. M. Vitousek ${ }^{5}$
}

\begin{abstract}
The leeward Kohala Field System on the island of Hawai'i was one of the most intensive pre-European contact dryland agricultural systems. Archaeological and soil analysis has documented changes in soil nutrients over time. Soils were collected under agricultural field walls of different relative ages within the Kohala Field System. These field walls preserved soil from the time of their construction (between ca. A.D. 1400 and 1800), so soil samples from underneath older field walls have been exposed to a shorter period of cultivation than the soils under more recent field walls. Total $\mathrm{P}$ and $\mathrm{P}: \mathrm{Nb}$ ratios of these buried soils were greater under walls than in once-cultivated surface soils, and greater under older walls than under younger walls. These results suggest that precontact cultivation decreased soil $\mathrm{P}$ reserves in this intensive agricultural landscape.
\end{abstract}

Before European contact, Hawaiians created and maintained a number of rain-fed dryland agricultural systems, mostly on the geologically younger islands of Hawai'i and Maui (Kirch 1985, 1994). These systems covered many kilometers with a fine-scale matrix of earth or rock field walls and paved trails (Clark 1987, Ladefoged 1993, Rosendahl 1994, Ladefoged and Graves 2000, 2005, Allen 2001, 2004, Ladefoged et al. 2003, Burtchard and Tomonari-Tuggle 2004, McCoy 2005). Both contemporary accounts at the time of European contact and the scope of the agricultural infrastructure make clear that these represented intensive agricultural systems by any measure. At least some of

${ }^{1}$ Research was funded by NSF biocomplexity grant BCS-0119819 and grants from the University of Auckland. Manuscript accepted 29 August 2006.

${ }^{2}$ Earth Systems Program, Stanford University, Stanford, California 94305.

${ }^{3}$ Current address: 1616 East Howell Street, Apartment 206, Seattle, Washington 98122.

${ }^{4}$ Department of Anthropology, University of Auckland, Auckland, New Zealand.

${ }^{5}$ Department of Biological Sciences, Stanford University, Stanford, California 94305.

${ }^{6}$ Corresponding author: t.ladefoged@auckland.ac.nz.

Pacific Science (2007), vol. 61, no. 3:347-353

(C) 2007 by University of Hawai'i Press

All rights reserved these systems were maintained for 200-500 yr before European contact (Rosendahl 1994, Coil 2004, Ladefoged et al. 2005; T.N.L. and M. W. Graves, unpubl. data), though most were abandoned shortly after contact as Hawaiian populations were devastated by introduced diseases.

To be sustained, intensive agriculture must replenish the nutrients that are removed in agricultural products or otherwise lost from perennially disturbed sites-and the more intensive the agriculture, the greater the challenge (Sanchez 1976). Modern agriculture replenishes nutrients through fertilization, whether by industrial or organic amendments. Hawaiians had no access to industrial fertilizer and no access to forms of energy (fossil fuels or even draft animals) that could help to distribute organic material. Although Hawaiian cultivators mulched extensively (Handy and Handy 1972), replacing the nutrients removed from soils by their crops cannot have been easy, and on the scale of the entire field systems it may not have been possible.

One way that Hawaiians did address the nutrient requirements of intensive agriculture was through their choice of areas to intensify. All of the large rain-fed systems occur in areas that represent "sweet spots" of rainfall and soil fertility. They receive enough rainfall to support crop growth in most years (Kirch 
1985) but not so much rain that nutrients have been removed from soils by tens to hundreds of thousands of years of leaching (Chadwick et al. 2003, Kirch et al. 2004, Vitousek et al. 2004). As soils grow progressively older, the cumulative effects of leaching cause these sweet spots to narrow and eventually to disappear, effectively confining most of the large rain-fed intensive agricultural systems to portions of the island of Hawai'i and to Haleakalā on Maui.

Could long-sustained intensive agriculture have caused the depletion of essential nutrients, even from the relatively nutrient-rich soils that were cultivated? If so, decreases in soil fertility could have decreased crop yield, stressing the productive system in the late precontact period, when Hawaiian populations were at or near their peak and demands for social production were high. Because of its mobility, nitrogen $(\mathrm{N})$ is the nutrient most likely to be depleted by intensive agriculture, but that mobility makes it difficult to infer past $\mathrm{N}$ dynamics from modern $\mathrm{N}$ pools. However, phosphorus $(\mathrm{P})$ also can limit crop production, especially in tropical systems, and its very low mobility makes its past dynamics more amenable to analysis.

Recent research shows that soil P is enriched within dryland agricultural systems, relative to adjacent drier and especially wetter sites (Kirch et al. 2004, Vitousek et al. 2004). The enhancement of resin-extractable $\mathrm{P}$ (more or less biologically available) is particularly striking on older Pololū substrates in leeward Kohala, Hawai'i: concentrations within the abandoned field system average $>125$ $\mu \mathrm{g} / \mathrm{g}$, versus $<20 \mu \mathrm{g} / \mathrm{g}$ for adjacent sites outside the system (Vitousek et al. 2004). Total $\mathrm{P}$ also is enriched within the field system, by two- to threefold relative to adjacent areas outside it and (in the younger Hāwī substrates) relative to basalt parent material as well.

Vitousek et al. (2004) evaluated possible reasons for this enrichment in total $\mathrm{P}$ by analyzing soils that had been buried under field walls when the dryland system was established. They reasoned that if mulching by Hawaiian cultivators were responsible, then any enrichment should be less under walls; if a natural process (such as "mining" of sub- soils by native forest vegetation, over millennia [Jobaggy and Jackson 2001]) were responsible, then underwall soils should be at least as enriched as surface soils within the field system. They found buried soils to be substantially more enriched in $\mathrm{P}$ than modern soils and concluded that a natural process was responsible for the elevated $\mathrm{P}$ within the field system. They further speculated that the difference in total $\mathrm{P}$ between the buried soils and surface soils within the field system could reflect nutrient depletion under centuries of intensive cultivation by Hawaiian farmers.

In this paper, we pursue that speculation by making use of additional samples of soils from under field walls in leeward Kohala. These additional collections were based upon relative chronologies of wall construction in three areas of the system. We tested whether the degree of $\mathrm{P}$ enrichment in buried soils correlates with the age of the walls that cover them, as would be expected if sustained cultivation causes $\mathrm{P}$ depletion.

\section{Study Area}

The Kohala Field System consists of ca. 60 $\mathrm{km}^{2}$ of precontact dryland agricultural fields on the leeward western slope of the Kohala Mountains on the island of Hawai'i. Polynesians cultivated the area from possibly as early as A.D. 1300 (Ladefoged et al. 2005) into the early historic period. The principal crop was sweet potato (Ipomoea batatas); other crops included yams (Dioscorea spp.), sugarcane (Saccharum officinarum), dryland taro (Colocasia esculenta), and bananas (Musa hybrids) (Ladefoged and Graves 2000, 2005). The annual rainfall within the field system ranges from 800 to $1,700 \mathrm{~mm}$ (Ladefoged et al. 1996, Ladefoged and Graves 2000). The basaltic substrate consists of lava flows from two volcanic formations, the $\sim 400,000$-yr-old Pololū Formation and the 150,000 -yr-old Hāwī Formation, both covered with deposits of tephra.

A system of trails and walls divides the agricultural fields within the Kohala Field System. The trails are stone, earth, or paved walkways that are parallel to the mountain slope, and the walls are stone and/or soil embankments perpendicular to the trails, the 
slope, and the persistent northeast trade winds. The walls are about $1-2 \mathrm{~m}$ in width, $0.5-1.5 \mathrm{~m}$ in height, and 7-590 $\mathrm{m}$ in length (Ladefoged et al. 2003). Ladefoged et al. (2003) (see also Ladefoged and Graves in press) analyzed the distributional pattern of the field walls and trails to understand the development of the agricultural systemmapping field walls and trails and determining the features' relative ages within each area based on their relative positions. This relative chronology provides a unique opportunity to evaluate changes in soil nutrient concentrations according to increasing agricultural intensification. Results of recent radiocarbon determinations generally confirm the relative ordering of the walls and trails, and place the development of the field system within the period from ca. A.D. 1400 to 1800 (T.N.L. and M. W. Graves, unpubl. data).

\section{MATERIALS AND METHODS}

In July 2004, 48 soil samples were collected under field walls of known relative ages within the Kohala Field System by digging through rock and soil field walls to access the soil underneath. Soils were collected from 0 to $30 \mathrm{~cm}$ below the lower boundary of the wall. After collection, soil clods were broken by hand, and each sample was air-dried and sieved. Samples were shipped to ALS Chemex (Sparks, Nevada) for analysis; total $\mathrm{P}$ was determined by $\mathrm{X}$-ray fluorescence following lithium metaborate fusion, and niobium $(\mathrm{Nb})$ was determined by pressedpellet wavelength-dispersive $\mathrm{X}$-ray fluorescence. The same provider and procedure have been used extensively in analyses of $\mathrm{Ha}-$ waiian soils (e.g., Chadwick et al. 1999, 2003, Vitousek et al. 2004), and analytical precision consistently has been high ( $<5 \%$ variation). We used $\mathrm{Nb}$ as an immobile index element to calculate the fraction of parent material $\mathrm{P}$ that remains within the soil (Kurtz et al. 2000)- $\mathrm{P}: \mathrm{Nb}$ ratios less than that in basalt indicate loss of $\mathrm{P}$, and larger $\mathrm{P}: \mathrm{Nb}$ ratios reflect enrichment of $\mathrm{P}$.

Samples were collected from three areas within the Kohala Field System: Kahuā Mauka, Kahuā Makai, and Lapakahi Makai (see Ladefoged and Graves [2006] for a discussion of these territorial units). The relative ages of the field walls within these areas were calculated using the methods of Ladefoged et al. (2003) and Ladefoged and Graves (in press). The Kahuā Makai and Lapakahi Makai sample areas were defined by two original trails connected by the oldest walls. More recently constructed trails divided the land between those trails (Figure 1), and the walls connecting the more recent trails were youn-

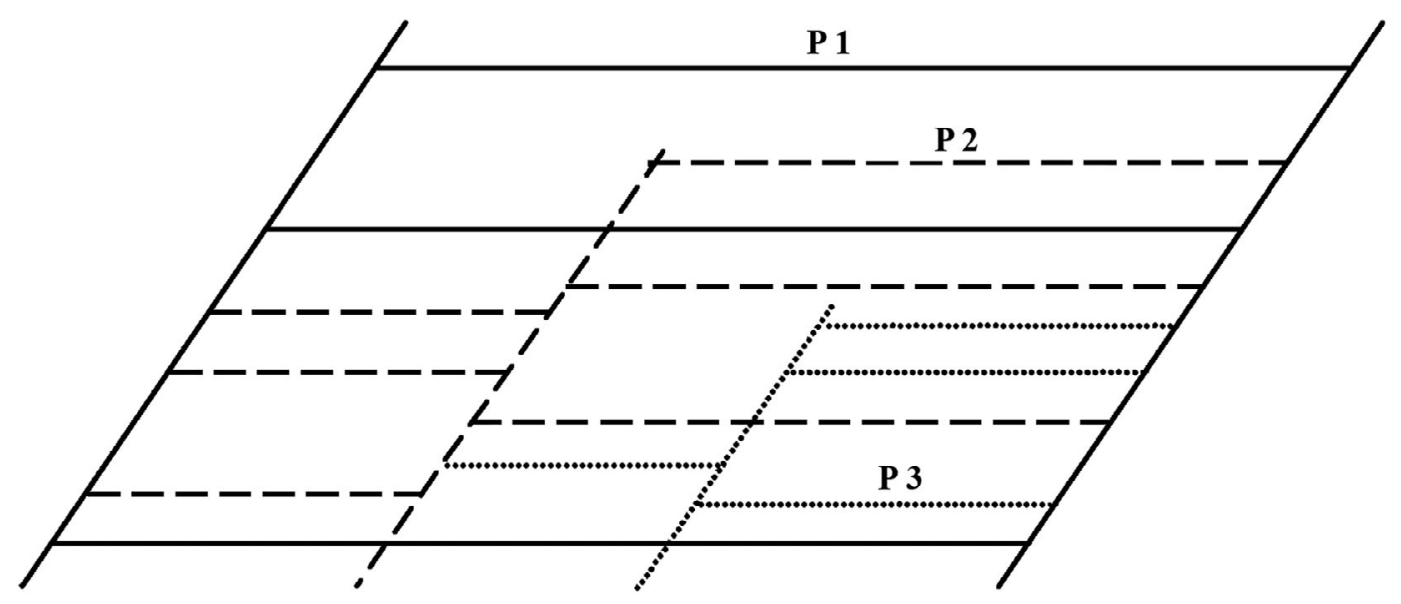

FIGURE 1. Schematic drawing of relative ages of field walls and trails within the Kohala Field System: the P1 (solid lines) field walls and trails are the relatively oldest features; the P2 (dashed lines) field walls and trails are the intermediate-aged features; and the P3 (dotted lines) field walls and trails are the most recent, or youngest, features. 


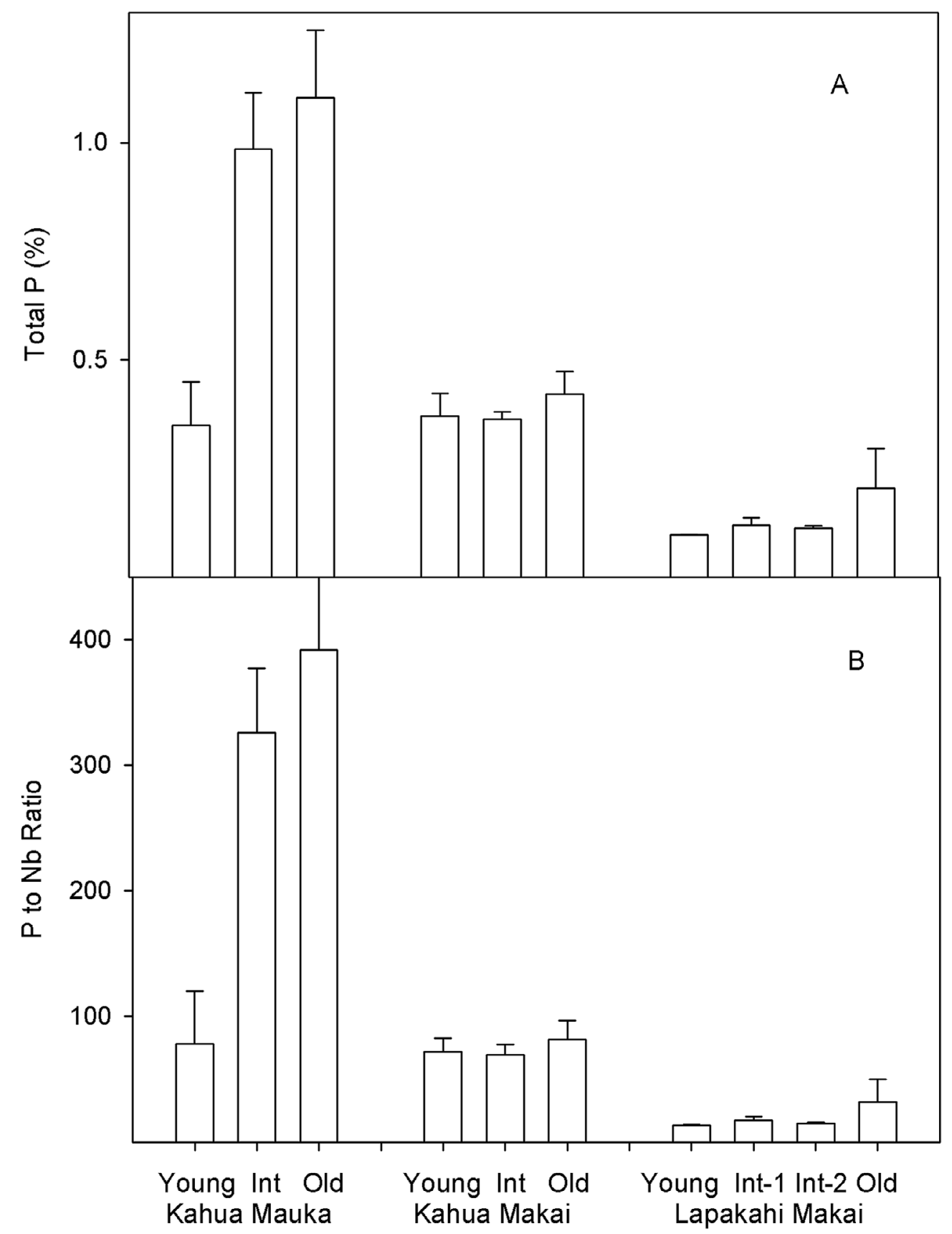

FIgUre 2. The total $\mathrm{P}(\%)(A)$ and $\mathrm{P}: \mathrm{Nb}$ ratio $(B)$ for underwall soil samples as a function of increasing relative age of field walls. 
ger, meaning that these walls capped soils that had been exposed to greater agricultural use. The Kahuā Mauka sample area was composed of two adjacent areas that each had two time periods; together they spanned three time periods.

We collected one underwall soil sample from each of five separate walls of each age class in each area, except for the youngest walls in Kahuā Mauka, where the results of four samples were obtained, and the oldest walls of Lapakahi Makai, where three underwall samples were collected. We used the Kruskal-Wallis $H$ test, a nonparametric ana$\log$ of one-way analysis of variance, to test whether the $\mathrm{P}$ and $\mathrm{P}: \mathrm{Nb}$ ratio levels for the walls assigned to the different phases were significantly different.

\section{RESULTS AND DISCUSSION}

Patterns of total $\mathrm{P}$ concentrations and $\mathrm{P}: \mathrm{Nb}$ ratios are summarized in Figure 2, and statistical results are summarized in Table 1 . Kahuā Mauka yielded a significant $(P<.05)$ relationship of increasing total $\mathrm{P}$ and $\mathrm{P}: \mathrm{Nb}$ ratios with increasing relative age of field walls (Figure 2). The results from Kahuā Makai do not differ significantly as a function of wall age, whereas the results from Lapakahi Makai yielded a significant $(P<.05)$ pattern of higher values under the older walls. Buried soils of the upper study area on the younger Hāwī substrate (the Kahuā Mauka area) had $\mathrm{P}: \mathrm{Nb}$ ratios greater than those in basaltic parent material (110 in Hāwī substrate and 84 in Pololū) and greater than those from nearby surface soil samples collected away from the walls within the Kohala Field System (Vitousek et al. 2004). Vitousek et al. (2004) suggested that the field walls capped the soil below them, largely preserving nutrient levels for the relatively immobile element P; they further suggested that the greater $\mathrm{P}: \mathrm{Nb}$ ratios below walls relative to surface soils reflect depletion of soil nutrients over time by Polynesian cultivators. Our results support this suggestion by demonstrating that the more recent walls capped soils with lower $\mathrm{P}$ concentrations, as would be expected if cultivation decreased $\mathrm{P}$ availability until the construction of the wall.

TABLE 1

Kruskal-Wallis $H$ Test Results for P and P:Nb Levels of Walls of Different Ages from Each Area

\begin{tabular}{|c|c|c|c|c|c|c|c|}
\hline Area & Chemical & Relative Age of Wall & No. & Mean Rank & Chi-Square & $\mathrm{df}$ & Asymp. Sig. \\
\hline \multirow[t]{6}{*}{ Kahuā Mauka } & \multirow[t]{3}{*}{$\mathrm{P}$} & 1 & 5 & 10.4 & \multirow[t]{3}{*}{8.463} & \multirow[t]{3}{*}{2} & \multirow[t]{3}{*}{.015} \\
\hline & & 2 & 5 & 8.6 & & & \\
\hline & & 3 & 4 & 2.5 & & & \\
\hline & \multirow[t]{3}{*}{$\mathrm{P}: \mathrm{Nb}$} & 1 & 5 & 10.4 & \multirow[t]{3}{*}{7.791} & \multirow[t]{3}{*}{2} & \multirow[t]{3}{*}{.02} \\
\hline & & 2 & 5 & 8.4 & & & \\
\hline & & 3 & 4 & 2.75 & & & \\
\hline \multirow[t]{6}{*}{ Kahuā Makai } & \multirow[t]{3}{*}{$\mathrm{P}$} & 1 & 5 & 9.6 & \multirow[t]{3}{*}{0.960} & \multirow[t]{3}{*}{2} & \multirow[t]{3}{*}{.619} \\
\hline & & 2 & 5 & 7.2 & & & \\
\hline & & 3 & 5 & 7.2 & & & \\
\hline & \multirow[t]{3}{*}{$\mathrm{P}: \mathrm{Nb}$} & 1 & 5 & 8.8 & \multirow[t]{3}{*}{0.260} & \multirow[t]{3}{*}{2} & \multirow[t]{3}{*}{.878} \\
\hline & & 2 & 5 & 7.4 & & & \\
\hline & & 3 & 5 & 7.8 & & & \\
\hline \multirow[t]{8}{*}{ Lapakahi Makai } & \multirow[t]{4}{*}{$\mathrm{P}$} & 1 & 3 & 15.33 & \multirow[t]{4}{*}{9.561} & \multirow[t]{4}{*}{3} & \multirow[t]{4}{*}{.023} \\
\hline & & 2 & 5 & 10.8 & & & \\
\hline & & 3 & 5 & 10.3 & & & \\
\hline & & 4 & 5 & 3.9 & & & \\
\hline & \multirow[t]{4}{*}{$\mathrm{P}: \mathrm{Nb}$} & 1 & 3 & 16 & \multirow[t]{4}{*}{9.168} & \multirow[t]{4}{*}{3} & \multirow[t]{4}{*}{.027} \\
\hline & & 2 & 5 & 9.8 & & & \\
\hline & & 3 & 5 & 10.4 & & & \\
\hline & & 4 & 5 & 4.4 & & & \\
\hline
\end{tabular}


Overall, our analyses suggest that over time Hawaiian agriculture decreased levels of $\mathrm{P}$ in soils of the Kohala Field System. The upper and wetter edge of the field system is close to a threshold in soil fertility described by Chadwick and Chorover (2001)—soil minerals here are nearly depleted and so a small increment in annual rainfall leads to a strong decline in soil nutrient availability. Consequently, any increase in losses associated with cultivation could drive soils across that threshold into infertility, causing the upper-elevation boundary of the potentially productive agricultural zone to shift downslope during the long period of precontact cultivation.

\section{ACKNOWLEDGMENTS}

We thank our colleagues on the NSF grant (Oliver Chadwick, Michael Graves, Sara Hotchkiss, Patrick Kirch, and Shripad Tuljapurkar) for their insights, and Heraldo Farrington, Tony Hartshorn, and Doug Turner for assistance with soil sampling and analysis. Julie Stein, Chris Lockwood, and Stephanie Jolivette have greatly enhanced our research. Permission to conduct fieldwork was provided by the State of Hawai'i, Division of Land and Natural Resources, and by Kahuā, Ponoholo, and Parker Ranches.

\section{Literature Cited}

Allen, M. S. 2001. The Kona Field System in spatial and temporal perspective. Pages 137-155 in M. S. Allen, ed. Gardens of Lono: Archaeological investigations at the Amy B. Greenwell Ethnobotanical Garden, Kealakekua, Hawai'i. Bishop Museum Press, Honolulu.

2004. Bet-hedging strategies, agricultural change, and unpredictable environments: Historical development of dryland agriculture in Kona, Hawaii. J. Anthropol. Archaeol. 23:196-224.

Burtchard, G. C., and M. J. TomonariTuggle. 2004. Agriculture on leeward Hawaii Island: The Waimea agricultural system reconsidered. Hawaii. Archaeol. 9:50-73.
Chadwick, O. A., and J. Chorover. 2001. The chemistry of pedogenic thresholds. Geoderma 100:321-353.

Chadwick, O. A., L. Derry, P. M. Vitousek, B. J. Huebert, and L. O. Hedin. 1999. Changing sources of nutrients during four million years of ecosystem development. Nature (Lond.) 397:491-497.

Chadwick, O. A., R. T. Gavenda, E. F. Kelly, K. Ziegler, C. G. Olson, W. C. Elliott, and D. M. Hendricks. 2003. The impact of climate on the biogeochemical functioning of volcanic soils. Chem. Geol. 202:195223.

Clark, J. T. 1987. Waimea-Kawaihae, a Leeward Hawaii settlement system. Ph.D. diss., University of Illinois, UrbanaChampaign.

Coil, J. H. 2004. "The beauty that was": Archaeological investigations of ancient $\mathrm{Ha}-$ waiian agriculture and environmental change in Kahikinui, Maui. Ph.D. diss., University of California, Berkeley.

Handy, E. S. C., and E. G. Handy. 1972. Native planters of old Hawaii: Their life, lore, and environment. Bernice P. Bishop Mus. Bull. 233.

Jobbagy, E. G., and R. B. Jackson. 2001. The distribution of soil nutrients with depth: Global patterns and the imprint of plants. Biogeochemistry (Dordr.) 53:51-77.

Kirch, P. V. 1985. Feathered gods and fishhooks : An introduction to Hawaiian archaeology and prehistory. University of Hawai' i Press, Honolulu. . 1994. The wet and the dry: Irrigation and agricultural intensification in Polynesia. University of Chicago Press, Chicago.

Kirch, P. V., A. S. Hartshorn, O. A. Chadwick, P. M. Vitousek, D. R. Sherrod, J. Coil, L. Holm, and W. D. Sharp. 2004. Environment, agriculture, and settlement patterns in a marginal Polynesian landscape. Proc. Natl. Acad. Sci. U.S.A. 101:9936-9941.

Kurtz, A. C., L. A. Derry, O. A. Chadwick, and M. J. Alfano. 2000. Refractory element mobility in volcanic soils. Geology (Boulder) 28:683-686.

Ladefoged, T. N. 1993. Hawaiian dryland ag- 
ricultural intensification and the Pacific economy. Pac. Stud. 16:119-131.

Ladefoged, T. N., and M. W. Graves. 2000. Evolutionary theory and the historical development of dry-land agriculture in North Kohala, Hawai'i. Am. Antiq 65 (3): $423-$ 448.

. 2005. Modelling the human ecodynamics of Kohala, Hawai'i. Pages 155160 in C. M. Stevenson, J. M. Ramirez Aliaga, F. J. Morin, and N. Barbacci, eds. The Rena Papers: VI International Conference on Rapa Nui and the Pacific/VI Congreso internacional sobre Rapa Nui y el Pacifico. Easter Island Foundation, Los Osos, California.

- 2006. The formation of Hawaiian territories. Pages 259-283 in I. Lilley, ed. Archaeology of Oceania. Blackwell Press, London.

- In press. Modeling agricultural development and demography in Kohala, Hawai'i. In P. V. Kirch and J.-L. Rallu, eds. Long-term demographic evolution in the Pacific islands. University of Hawai' $i$ Press, Honolulu.

Ladefoged, T. N., M. W. Graves, and J. Coil. 2005. The introduction of sweet potato in
Polynesia: Early remains in Hawai'i. J. Polynesian Soc. 114:359-373.

Ladefoged, T. N., M. W. Graves, and R. P. Jennings. 1996. Dryland agricultural expansion and intensification in Kohala, Hawai'i Island. Antiquity 70:861-880.

Ladefoged, T. N., M. W. Graves, and M. D. McCoy. 2003. Archaeological evidence for agricultural development in Kohala, Island of Hawai'i. J. Archaeol. Sci. 30:923940.

McCoy, M. 2005. The development of the Kalaupapa Field System, Moloka'i Island, Hawai'i. J. Polynesian Soc. 114:339-358.

Rosendahl, P. H. 1994. Aboriginal Hawaiian structural remains and settlement patterns in the upland agricultural zone at Lapakahi, Island of Hawai'i. Hawaii. Archaeol. 3:14-70.

Sanchez, P. A. 1976. Properties and management of soils in the Tropics. John Wiley and Sons, New York.

Vitousek, P. M., T. N. Ladefoged, P. V. Kirch, A. S. Hartshorn, M. W. Graves, S. C. Hotchkiss, S. Tuljapurkar, and O. A. Chadwick. 2004. Soils, agriculture, and society in precontact Hawai'i. Science (Washington, D.C.) 304:1665-1669. 
